\title{
Growing Up with My Brother, Doctor Don: Interview with Charles Lindberg
}

\author{
Robert A. LOGAN Ph.D. \\ U.S. National Library of Medicine (retired) ${ }^{1}$
}

Keywords. Donald A.B. Lindberg M.D., Lindberg family history, Brooklyn

In a spring 2021 interview, Charlie Lindberg remembered his Brooklyn-based childhood and the life-long assistance of his older brother, Donald A.B. Lindberg M.D.

As Charlie called him throughout his adult life, 'Dr. Don' helped Charlie when he a teenager by lending him an ID. Charlie explained in the 1940s-50s, identity cards did not include someone's photo. 'Dr. Don's ID said light brown hair, blue eyes, thin, and about 6.5 feet tall, which described him as well as me.'

'So when he (Dr. Don) was 14, I was 12.'

Using Dr. Don's ID on occasion, Charlie was more eligible to work and perhaps buy a beer. (Charlie explained the legal drinking age in New York City at the time was 18).

Charlie's teen odd jobs included parking cars at Lundy's seafood restaurant, shining shoes near a Kings Highway bus/subway stop, and diving for coins at the Sheepshead Bay waterfront. Charlie joked how much further money went during his formative years: 'If I shined shoes for a nickel and made 40 cents, I was a millionaire.' He explained a movie was 12 cents, candy and some soft drinks at the theater were just two cents.

Charlie added if he shined shoes on Wednesday, Friday, and Saturday or dived for coins in the summer, he could clear 75 cents a day. Besides going to the movies, Charlie said he could bike to Ebbets Field (to watch the Brooklyn Dodgers baseball team), pay 60 cents for a bleacher seat, spend 10 cents for popcorn - 'and still have change.'

"It was safe and free to park your bike near the ballpark. I never experienced vandalism or a stolen bike.'

With a sense of nostalgia coupled with amusement, Charlie underscored that during his childhood. some urban roads were unpaved, and Brooklyn seemed to be a big village of residents who sometimes befriended social innocence.

'I know it sounds strange to kids today - but living was much easier back then.'

To provide an example of Dr. Don's escapades and illustrate how urban environments and American culture have changed in 75 years, Charlie noted one of Dr. Don's pastimes was his active participation in the rifle club at Poly Prep Country Day School.

For outdoor practice, Charlie explained Dr. Don would carry a rifle almost as is, take the 22 bus in Brooklyn to the BMT (train), which took him to the School's practice facility. Don took this routine journey throughout high school sans problems. 'Can you imagine anyone pulling this off today?' Charlie asked.

Charlie added Dr. Don could practice indoors in the basement of the Lindberg's Brooklyn brownstone home. Charlie noted Brooklyn's mid- $20^{\text {th }}$ century brownstone

\footnotetext{
${ }^{1}$ Corresponding author: logrob@gmail.com
} 
homes - often built less than a century earlier - featured large, long, accessible basements. Until the second decade of the $20^{\text {th }}$ century, the sizeable cellars served as the place for a family's horses and wagons. Charlie continued that some brownstone basements were so well constructed and insulated that the Lindberg's neighbors never noticed Don's rifle range activities.

During this era, Charlie explained he and his brother frequently helped their father, an architect. For example, Charlie and Dr. Don measured some distances within garages that were undergoing an overhaul. Charlie explained garage renovations boosted business for architects because the use of garages shifted in the $20^{\text {th }}$ century from horse stables to electric cars, to internal combustion cars and trucks, to other family or work conversions.

He said their father (Harry Bror Lindberg) also architecturally designed bottling plants for Pepsi, Coca-Cola, and a local dairy. Harry Lindberg additionally designed the first color television studio in Brooklyn, the renovation of the Lunt-Fontanne Theater on Broadway, and the home of American philanthropist Mary Duke Biddle. Charlie noted the Biddle house featured a then-rare bowling alley in the basement.

Skipping ahead to the era when the Lindberg brothers were in their early 20 s, Charlie noted automobiles were so inexpensive that both he and Don could purchase one for $\$ 25$ $\$ 60$. When U.S. gas prices spiked two generations later, Charlie recalled Dr. Don once paid $\$ 80$ to simultaneously fill three tanks for himself, Charlie, and Mary Lindberg. As he paid the bill, Don remarked to Charlie: 'do you realize we could buy a car for less money only 40 years ago!'

Charlie said Dr. Don's favorite automobile was a 1929 Chandler 8 that he purchased for $\$ 60$. A framed ad for a Chandler sits in Don's home library. Don could climb in with a slight head turn to the right when he was at his desk.

Moving to September 11, 2001, Charlie was pitching in Fairfax. VA. during a Virginia senior league softball game at the time a passenger jet deliberately flew into the U.S. Pentagon. Fairfax is geographically adjacent to the Pentagon. As a U.S. military veteran and a dedicated softball pitcher, the experience left a deep impression. Charlie moved to his current residence in the western U.S. state of Oregon precisely a year later.

At the moment Charlie left the pitching mound during the Pentagon attack, Dr. Don was hosting the U.S. National Library of Medicine's (NLM) Board of Regents meeting in nearby Bethesda. Some of the developments at NLM on 9/11 are described in Joyce Mitchell's memoir within the current book [1].

Charlie worked for RCA and IBM for many years and at times lived in the same area as Don and Mary Lindberg. Throughout the past 50 years, Charlie has spent significant time with members of the Lindberg family with whom he remains happily in touch.

'Dr. Don was a great, gifted man. However, to me, he will always be my helpful older brother...'

\section{References}

[1] Mitchell JA. Donald A.B. Lindberg M.D. - my mentor. In: Humphreys BL, Logan RA, Miller RA, Siegel ER, editors. Transforming biomedical information and health information access: Don Lindberg and the National Library of Medicine. Amsterdam: IOS Press; 2021. 